\title{
Erratum to: Genome-wide incorporation dynamics reveal distinct categories of turnover for the histone variant $\mathrm{H} 3.3$
}

Daniel C. Kraushaar ${ }^{1 \dagger}$, Wenfei Jin ${ }^{1 \dagger}$, Alika Maunakea ${ }^{1}$, Brian Abraham', Misook Ha ${ }^{2}$ and Keji Zhao ${ }^{1 *}$

After the publication of this work [1] an error was noticed in Fig. 1d. In the DAPI columns the same image was used accidentally for the $48 \mathrm{~h}$ and $72 \mathrm{~h}$ timepoints. The corrected figure is shown below. We apologize for this error.

\footnotetext{
Author details

'Systems Biology Center, National Heart, Lung, and Blood Institute, NIH, Bethesda, MD 20892, USA. ${ }^{2}$ Samsung Advanced Institute of Technology, Samsung Electronics Corporation, Yongin-Si, Gyeonggi-Do 446-712,

South Korea.
}

Received: 25 January 2016 Accepted: 25 January 2016

Published: 4 February 2016

\section{References}

1. Kraushaar DC, Jin W, Maunakea A, Abraham B, Ha M, Zhao K. Genome-wide incorporation dynamics reveal distinct categories of turnover for the histone variant H3.3. Genome Biol. 2013;14:R121.

\footnotetext{
*Correspondence: zhaok@nhlbi.nih.gov

${ }^{\dagger}$ Equal contributors

'Systems Biology Center, National Heart, Lung, and Blood Institute, $\mathrm{NIH}$, Bethesda, MD 20892, USA

Submit your next manuscript to BioMed Central and we will help you at every step:

- We accept pre-submission inquiries

- Our selector tool helps you to find the most relevant journal

- We provide round the clock customer support

- Convenient online submission

- Thorough peer review

- Inclusion in PubMed and all major indexing services

- Maximum visibility for your research

Submit your manuscript at www.biomedcentral.com/submit 
A

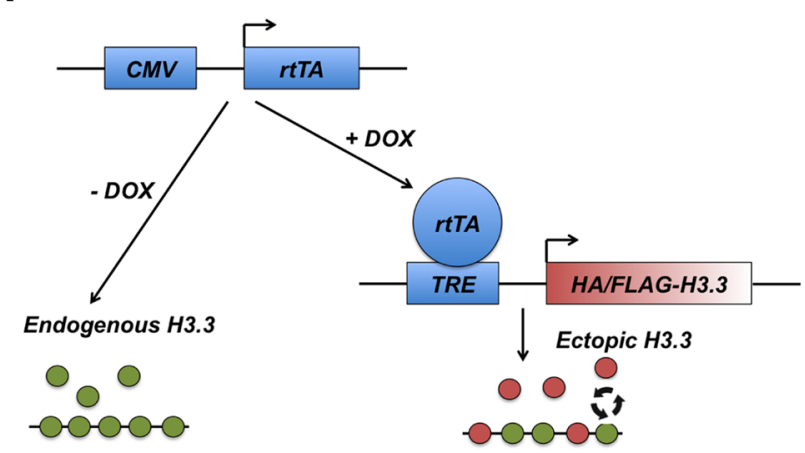

C
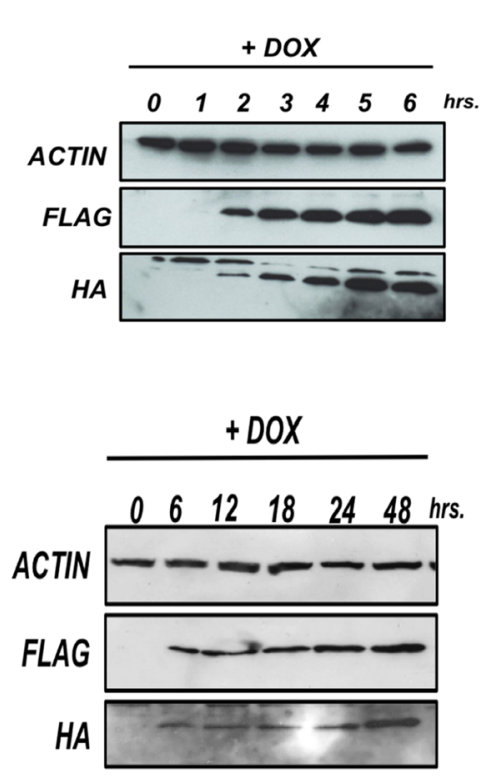

D

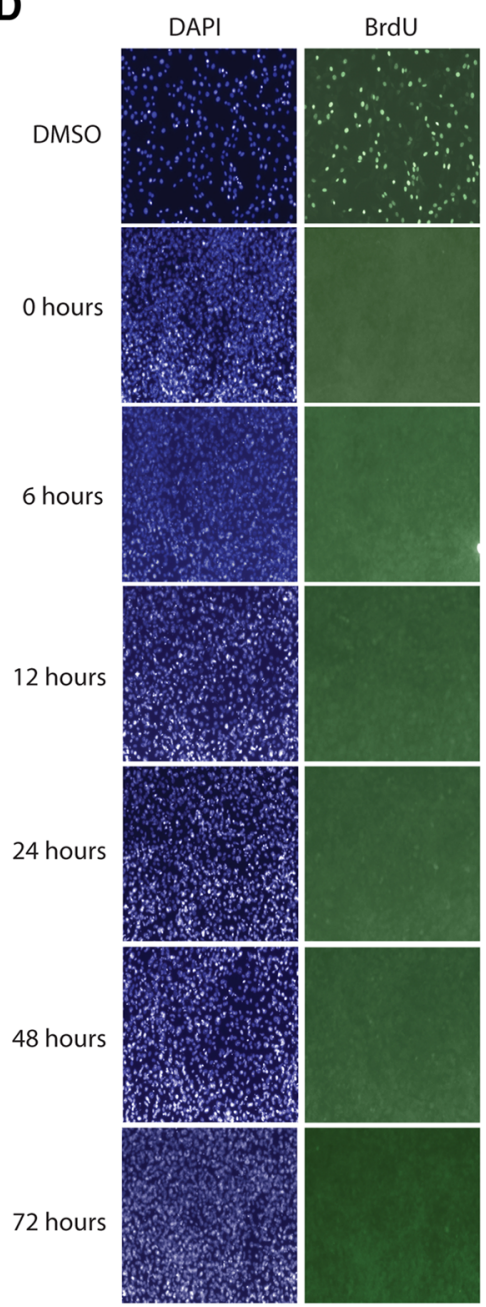

B

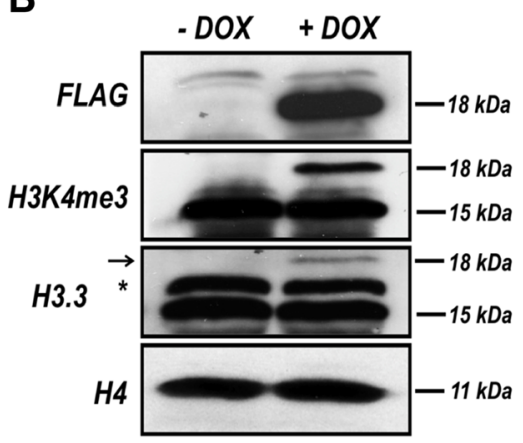

E

DMSO

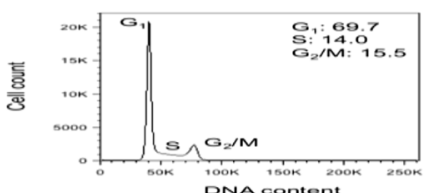

0 hours
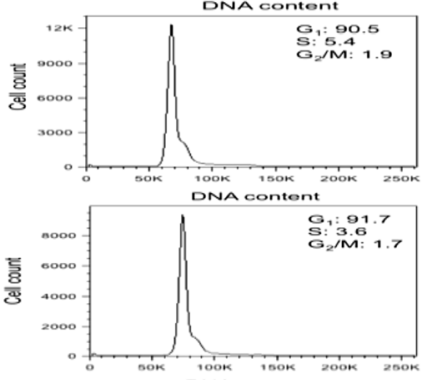

12 hours

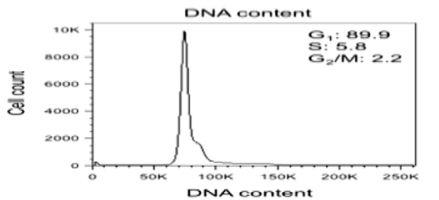

24 hours

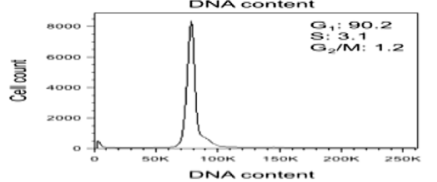

48 hours

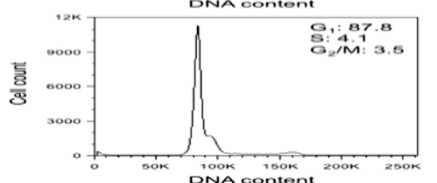

72 hours

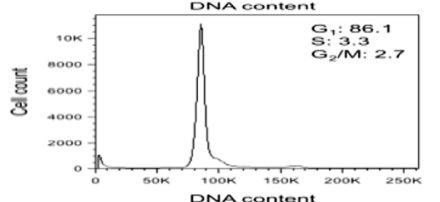

Fig. 1 A versatile system to study replication-independent nucleosome dynamics in mammals. (a) Schematic of TET-inducible expression system to study H3.3 turnover. CMV, cytomegalovirus; rtTA, reverse tetracycline-controlled transactivator; TRE, tetracycline responsive elements. (b) Western blot showing protein levels of transgenic HA/FLAG-H3.3 compared to endogenous H3.3. HA/FLAG-H3.3 expression 24 hours after DOX addition. The band marked with an asterisk is non-specific. The arrow marks transgenic HA/FLAG-H3.3. (c) Time course western blots of HA/FLAG-H3.3 expression. (d) Bromodeoxyuridine (BrdU) immunostaining of NIH/3 T3 cells treated with DNA polymerase inhibitor aphidicolin and DOX across time points of H3.3 induction. DMSO, dimethylsulfoxide. (e) Cell cycle analysis of cells treated with aphidicolin/DOX. Cells were stained with propidium iodide and analyzed by flow cytometry 